\title{
Sporangia Production Over Time by Phytophthora ramorum on Rhododendron 'Cunningham's White' After Placement at Different Relative Humidities
}

\author{
Paul W. Tooley† and Marsha Browning
}

United States Department of Agriculture-Agricultural Research Service, Foreign Disease-Weed Science Research Unit, 1301 Ditto Ave., Ft. Detrick, MD 21702.

Accepted for publication 11 January 2018.

\begin{abstract}
We examined the impact of relative humidity (RH) on Phytophthora ramorum sporangia production on Rhododendron 'Cunningham's White'. When diseased plants were maintained under continuous moisture in a mist tent, sporangia were collected from some plants for 22 weeks. More than 3,000 sporangia/leaf/week were collected over the first 3 weeks but levels declined to $<100$ sporangia/leaf/week after 7 weeks. We also examined the impact of drying on P. ramorum sporangia production. Diseased, detached leaves were maintained in humidity chambers $(100,96.2,84.5,74.9$, and $56.2 \% \mathrm{RH}$ ) for up to 9 weeks and removed weekly to assess sporulation.

For comparison, diseased leaves were harvested from plants maintained with dry foliage or subjected to $10 \mathrm{~h}$ of simulated dew nightly. All leaves supported sporulation following 5 weeks at $100 \% \mathrm{RH}, 3$ weeks at $96.2 \%$ $\mathrm{RH}$, and 1 week at $84.5 \% \mathrm{RH}$. All leaves collected from plants subjected to nightly dew supported sporulation for 3 weeks; however, only $66.7 \%$ of leaves collected from plants with dry foliage supported sporulation after 1 week. Knowledge of the effects of RH levels on P. ramorum sporulation capacity will prove useful in terms of disease management recommendations and for development of predictive models and pest risk assessments.
\end{abstract}

Phytophthora ramorum is the oomycete pathogen that causes sudden oak death in coastal California and Oregon (Frankel 2008; Frankel and Palmieri 2014; Rizzo et al. 2002; Werres et al. 2001) and ramorum blight of a number of nursery host species (Davidson et al. 2003; Shishkoff 2006). Economic losses are extensive, and include both direct losses to the nursery industry (Dart and Chastagner 2007; Suslow 2006) as well as societal costs associated with monitoring and regulatory efforts of various state and federal agencies (USDAAPHIS 2012; USGAO 2006). Sporangia are the primary means of dissemination for many species of Phytophthora (Erwin and Ribeiro 1996). Epidemics in the wild caused by $P$. ramorum are created by sporangia production on various host species such as California bay laurel, which has been shown to drive epidemics in California oak forests (Davidson et al. 2005, 2008). The sporangia production capacity of $P$. ramorum has been assessed on various hosts, including northern red oak and chestnut oak (Tooley et al. 2011), Camellia spp. (Linderman and Davis 2007), coast live oak (Vettraino et al. 2008), various European tree species (Denman et al. 2006), Mediterranean woody species (Moralejo et al. 2006), various New Zealand flora (Hüberli et al. 2008), and selected understory hosts (Tooley and Browning 2009). In previous studies, we have assessed recovery of $P$. ramorum in leaf disks held in soil at various temperatures for extended periods of time (Tooley et al. 2008), assessed temperature effects on the onset of sporulation (Tooley and Browning 2015), and determined the effects of varying relative humidity $(\mathrm{RH})$ treatments on the viability of $P$. ramorum sporangia (Tooley and Browning 2016). However, the longevity of sporangia production on specific hosts, and the effects of incubation of diseased leaves at suboptimal RH levels on subsequent sporangia production, have not been assessed.

${ }^{\dagger}$ Corresponding author: P. W. Tooley; E-mail: paul.tooley@ars.usda.gov

This article is in the public domain and not copyrightable. It may be freely reprinted with customary crediting of the source. The American Phytopathological Society, 2018.
Knowledge of the ultimate capacity of $P$. ramorum to produce sporangia over time under optimum conditions is important for epidemiological modeling and prediction of maximum spore loads. Knowledge of effects of periods of suboptimal RH on subsequent sporulation capacity of $P$. ramorum will aid in understanding the pathogen's propensity to initiate epidemics following hot, dry summers that occur in regions of California and elsewhere that experience a Mediterranean climate. For example, it has been observed that a dormant period exists for $P$. ramorum during summers in regions of California where the pathogen is established, when it is difficult to isolate viable samples from host tissue (Davidson et al. 2005, 2008, 2011). Inoculum levels have been correlated with periods of high moisture and rainfall that occur at other times of the year (Davidson et al. 2002, 2008). Knowledge of the specific effects of reduced humidity levels on diseased tissue and its subsequent ability to support $P$. ramorum sporulation will allow a greater understanding of epidemic dynamics, including levels of initial inoculum to be expected once moist conditions again occur. Thus, the focus of these studies was to determine the maximum capacity of $P$. ramorum to produce sporangia over time at high $\mathrm{RH}$, and to assess the propensity of $P$. ramorum to sporulate following prolonged periods at suboptimal levels of RH. Sporulation parameters determined in these studies can be used in models of pathogen development (Quinn and Fujimoto 1986), and can also provide data to be used in pest risk assessments (Cave et al. 2005; Sansford et al. 2010).

\section{MATERIALS AND METHODS}

P. ramorum isolate Cam 5C (NA1 clonal lineage) (Grünwald et al. 2009), isolated from Camellia sasanqua 'Bonanza' in California in 2003, was utilized in this study. Cultures were maintained on $10 \%$ V8-juice agar at $20^{\circ} \mathrm{C}$ in darkness. Sporangia for inoculations were produced by incubating mycelium-infested agar plugs in sterile soil extract, as described by Tooley et al. (2004).

Sporangia production in continuous moisture. Rhododendron plants were obtained commercially and were grown in Fafard 52 
potting mix (peat moss, bark, perlite, vermiculite, limestone, and wetting agent; proportions not provided on manufacturer's website) in 0.768 -liter pots $(10.16 \mathrm{~cm}$ in diameter by $13.0175 \mathrm{~cm}$ deep) and fertilized with Osmocote 20-20-20. Six Rhododendron 'Cunningham's White' plants (approximately 4 years old) were spray inoculated with approximately 3,000 sporangia/ml (approximately $30 \mathrm{ml} / \mathrm{plant}$ ) and incubated in a dew chamber (inner dimensions 75 by 75 by $150 \mathrm{~cm}$ high) at $20^{\circ} \mathrm{C}$ in darkness for 7 days to allow infection by $P$. ramorum. A mist tent, constructed of PVC pipe and plastic sheeting (274 by 91 by $137 \mathrm{~cm}$ high) and placed in a climate-controlled $\left(20^{\circ} \mathrm{C}\right)$ cubicle in a level BSL-3 containment greenhouse (Melching et al. 1983), was utilized for sporangia collection. Infected plants were removed from dew chambers and transferred to the mist tent. Each plant was propped on its side so that a section of closely aggregated leaves (mean $n=$ 8.33 leaves, range 5 to 11 ) extended over a 20.3-cm-diameter screen made of a cylindrical piece of PVC pipe and $15-\mu \mathrm{m}$ mesh size nitrile fabric (Sefar America, Buffalo, NY) affixed to one end of the pipe. All other leaves were removed. Misting nozzles located above the plants inside the mist tent were programmed to activate for $12 \mathrm{~s}$ every $4 \mathrm{~min}$ at a rate of 4.92 liters/h to maintain leaf wetness and facilitate movement of dehisced sporangia from diseased leaves into the screens. Some diseased leaves were shed from plants over time. These detached leaves were collected and placed into the PVC pipeconstructed screens, abaxial side up. Sporangia were collected two times per week by rinsing them from the collection screens with a squirt bottle filled with tap water into 50-ml centrifuge tubes. Volumes were standardized at $30 \mathrm{ml}$. The number of sporangia in three 1-ml aliquots was determined through direct counting, diluting when necessary. The sporangia suspension was transferred to plastic petri dishes ( 60 by $15 \mathrm{~mm}$ ) placed atop a $3-\mathrm{mm}$ grid printed on an acetate sheet, and sporangia were counted at $\times 40$ magnification under darkfield optics on a dissecting microscope. When no sporangia were observed in 1-ml subsamples, the entire sample was examined for spores. The total number of sporangia collected over 7 days was divided by the number of leaves in a clump to yield the number of sporangia per leaf. Two replicate experiments were performed.

Sporangia production following exposure to varied RH levels. Four experiments were completed with some modifications (Table 1). Diseased, detached leaves, produced initially by sporangia inoculation (experiments 1 and 2), then subsequently by plug inoculation (experiments 3 and 4), were incubated in humidity chambers for weekly periods of up to 9 weeks. Humidity levels were produced and controlled as described by Forney and Brandl (1992) and Winston and Bates (1960). Humidity chambers were constructed from Rubbermaid StainShield plastic storage containers (approximately 15.9 by $15.9 \mathrm{~cm}$ at base, 20.3 by $20.3 \mathrm{~cm}$ at the top, with a height of $8.6 \mathrm{~cm}$; volume $=2.0$ liters $)$. A glycerin solution ( $150 \mathrm{ml}$ ) of $0,20,40$ (experiments 2,3 , and 4 only), 60 , or $80 \%$ (aqueous, vol/vol) was added to each container to produce $\mathrm{RH}$ levels of 100, 96.2, 84.5, 74.9, and 56.2\%, respectively. RH levels inside chambers were monitored with small HOBO model H08007-02 data loggers (Onset Computer Corporation, Bourne, MA). A shelf to hold leaves above the glycerin solution was created by positioning a sheet of plastic mesh (2-mm openings) on top of plastic rings cut from drinking cups to a height of $1.5 \mathrm{~cm}$. Plastic mesh was also used to divide the area above the shelf into three compartments. Humidity chambers were held in an incubator programmed for $20^{\circ} \mathrm{C}$ in darkness.

Experiments 1 and 2. Eight Rhododendron 'Cunningham's White' plants (approximately 4 years old) were spray inoculated with approximately 3,000 sporangia/ml (approximately $30 \mathrm{ml} /$ plant) and incubated in dew chambers at $20^{\circ} \mathrm{C}$ in the dark for 5 days to allow infection to occur. Three plants were removed from dew chambers, placed on a greenhouse bench, and watered daily with drip emitters so that foliage would remain dry throughout the experiment. The greenhouse bench treatment was included to see whether $P$. ramorum sporulation was greater in attached, diseased leaves maintained at low RH $(43.3 \% \pm 9.2)$ compared with detached leaves exposed to low humidities. Diseased leaves were collected from the remaining five plants, blotted dry, then held in a 3.79-liter Ziploc bag while humidity chambers were prepared. Leaf age and position were not taken into account when collecting diseased leaves; however, young, succulent leaves were not utilized. Thirty-six leaves were selected at random from the bag and distributed within each humidity chamber, propping leaves up against the sides of each compartment to facilitate humidity equilibration within the chambers.

To assess sporangia production, three leaves were removed at weekly intervals from each chamber and positioned individually (abaxial side up) in 7.6-cm-diameter screens $(15-\mu \mathrm{m}$ mesh openings) inside the $20^{\circ} \mathrm{C}$ mist tent described above, with fogging nozzles activated for $12 \mathrm{~s}$ every $4 \mathrm{~min}$ to maintain leaf wetness. One diseased leaf was also harvested from each of the three greenhouse plants and placed individually in screens in the mist tent. After $72 \mathrm{~h}$ in the mist, screens were rinsed into 50-ml tubes and volumes adjusted to $20 \mathrm{ml}$. The number of sporangia in a $0.5-\mathrm{ml}$ subsample was determined through direct counting. When no sporangia were observed in the subsample, the entire sample was examined for sporangia. Leaves were scanned and lesion area determined with ASSESS software (Lamari 2002). Lesions were plated onto PARPH selective medium (Jeffers and Martin 1986; Ferguson and Jeffers 1999) containing $2 \%$ V8 juice (hereafter referred to as PARPH-V8) following sporangia collection in experiment 1 to determine whether $P$. ramorum was still viable in rehydrated, diseased leaves. Pathogen presence was confirmed microscopically using morphological criteria, including presence of characteristic chlamydospores (Werres et al. 2001). In experiment 2, leaf hydration levels (percent moisture) were determined gravimetrically: fresh weight was determined postincubation in humid chambers, and oven dry

TABLE 1. Treatments for sporangia production on Phytophthora ramorum-infected rhododendron leaves subjected to different relative humidities (RH)

\begin{tabular}{|c|c|c|c|c|}
\hline Variables & Experiment 1 & Experiment 2 & Experiment 3 & Experiment 4 \\
\hline Method of inoculation & $\begin{array}{l}\text { Sporangia suspension, } \\
5 \text { days in dew }\end{array}$ & $\begin{array}{l}\text { Sporangia suspension, } \\
5 \text { days in dew }\end{array}$ & $\begin{array}{l}\text { Wound/plug inoculation, } \\
7 \text { days in humid chamber }\end{array}$ & $\begin{array}{l}\text { Wound/plug inoculation, } \\
7 \text { days in humid chamber }\end{array}$ \\
\hline \multicolumn{5}{|c|}{ Treatment of diseased leaves ${ }^{y}$} \\
\hline Detached leaves & $\begin{array}{l}\text { Exposed to } 100,96.2,74.9, \\
\text { and } 56.2 \% \mathrm{RH}\end{array}$ & $\begin{array}{l}\text { Exposed to } 100,96.2,84.5 \text {, } \\
74.9, \text { and } 56.2 \% \mathrm{RH}\end{array}$ & $\begin{array}{l}\text { Exposed to } 100,96.2 \text {, } \\
84.5,74.9 \text {, and } 56.2 \% \mathrm{RH}\end{array}$ & $\begin{array}{l}\text { Exposed to } 100,96.2 \text {, } \\
84.5,74.9 \text {, and } 56.2 \% \mathrm{RH}\end{array}$ \\
\hline Sporangia production & $\begin{array}{l}\text { Detached leaves held in } \\
\text { mist } 72 \mathrm{~h}^{\mathrm{z}}\end{array}$ & $\begin{array}{l}\text { Detached leaves held in } \\
\text { mist } 72 \mathrm{~h}\end{array}$ & $\begin{array}{l}\text { Detached leaves held } \\
\text { in mist } 72 \mathrm{~h}\end{array}$ & Detached leaves held in mist $72 \mathrm{~h}$ \\
\hline
\end{tabular}

$\mathrm{y}$ Treatment of diseased leaves prior to sporangia production. Greenhouse bench = following inoculation, plants were maintained in a greenhouse with dry foliage and $10 \mathrm{~h}$ of dew nightly = plants were subjected to $10 \mathrm{~h}$ of simulated dew nightly in a greenhouse mist tent. Detached leaves were held in humidity chambers containing glycerin solutions to produce $\mathrm{RH}$ values of 100 to $56.2 \% \mathrm{RH}$.

$\mathrm{z}$ Three leaves per treatment were collected weekly and positioned in screens $(15-\mu \mathrm{m}$ pore size) in a mist tent to assess sporangia production over a 9 -week period. 
weight was determined following $72 \mathrm{~h}$ of leaf incubation in the mist tent. After leaves were scanned to determine lesion area, leaves were placed individually in labeled paper envelopes and placed in an oven at $100^{\circ} \mathrm{C}$ for 1 week. Leaves were then weighed to obtain oven dry weights.

Experiments 3 and 4 . We observed extreme desiccation of diseased leaf tissue soon after the removal of plants from dew chambers. This was especially evident on the plants maintained on a greenhouse bench with dry foliage. In an effort to remove this variable from our examination of the effects of RH on subsequent sporangia production by $P$. ramorum, an alternative inoculation technique was utilized in two additional experiments. Leaves on 11 plants were wounded to a depth of $0.5 \mathrm{~mm}$ with the tip of a sharpened metal probe $(0.75 \mathrm{~mm}$ in diameter $)$ and a 3 -mm-diameter agar plug removed from an approximately 7-day-old colony was inverted over the wounded area on each adaxial leaf surface. Plants were placed in humid chambers constructed from plastic bags in which plants were sealed, along with a beaker filled with water, and incubated for 7 days in a shaded, climate-controlled $\left(20^{\circ} \mathrm{C}\right)$ greenhouse cubicle. Upon removal from bags, leaves were wiped clean with moistened cheesecloth. Three plants were placed on a greenhouse bench and maintained with dry foliage. An additional treatment of greenhouse plants receiving $10 \mathrm{~h}$ of simulated dew nightly was included as a direct comparison with greenhouse plants maintained with dry foliage to see if wetting of the foliage would increase the likelihood of $P$. ramorum to survive and sporulate in diseased leaf tissue. Three plants were held in a mist tent in a climate-controlled greenhouse $\left(20^{\circ} \mathrm{C}\right)$ and exposed to natural light. Plants were misted every night (fogging nozzles activated for $20 \mathrm{~s}$ every $12 \mathrm{~min}$ ) over a 10 -h period to simulate the deposition of dew. The average ( $24 \mathrm{~h}$ ) $\mathrm{RH}$ in the mist tent determined using HOBO data loggers placed above the fogging nozzles (because they are not able to function when wet) was $64.5 \pm 13.3 \%$. Diseased leaves were collected from the remaining five plants and placed in humidity chambers at 100, 96.2, 84.5, 74.9, and 56.2\% RH, as described above. Three diseased leaves were harvested weekly from humidity chambers and positioned in screens in a mist tent to evaluate sporangia production by $P$. ramorum over a 72 -h period. One leaf was collected from each of the three plants maintained with dry foliage and also from the three plants subjected to nightly dew. Sporangia were harvested and counted as described above. Leaves were scanned and lesion areas determined. Data are presented as the mean number of sporangia produced per leaf and per square centimeter of lesion area from a total of 12 leaves ( 6 for plants subjected to dew)/treatment/exposure. Recovery of $P$. ramorum on PARPH-V8 was evaluated in experiment 3 and leaf hydration was evaluated in experiment 4 , as described above.

Enhanced recovery of $\boldsymbol{P}$. ramorum. To confirm the lack of survival of $P$. ramorum in leaves held at the lower $\mathrm{RH}$, an additional experiment was conducted utilizing an extended period of moist incubation at $4^{\circ} \mathrm{C}$, which has been demonstrated to enhance recovery of $P$. ramorum (Tooley and Carras 2011). Diseased leaves were produced on plants with the wound or plug inoculation technique followed by incubation in plastic bags, as described above. Leaf surfaces were cleaned with moistened cheesecloth. Forty leaves were placed in humidity chambers at $100,96.2,84.5,74.9$, or $56.2 \% \mathrm{RH}$. Chambers were placed in a $20^{\circ} \mathrm{C}$ incubator in the dark. Three leaves were removed from each humidity chamber following 1, 3, 4, 5, 6, 7, 14,21 , or 28 days of incubation. Three sections (approximately 2 by $2 \mathrm{~mm}$ ) were excised from the perimeters of lesions on each of three leaves and plated on PARPH-V8. The same leaves were then placed individually in plastic bags $(12.7$ by $12.7 \mathrm{~cm})$ filled with moistened vermiculite. Bags were sealed and stored in a $4{ }^{\circ} \mathrm{C}$ cooler. After 2 months, leaves were removed and rinsed clean of vermiculite. Three sections per leaf were removed and plated. Recovery rates preand post $-4^{\circ} \mathrm{C}$ storage were compared. The presence of the pathogen was confirmed microscopically using morphological criteria, as described above.
Statistical analyses. Continuous moisture and varied $\mathrm{RH}$ level data were analyzed via analysis of variance (ANOVA) using the general linear models procedure, and mean comparisons were performed using Tukey's test (Tukey 1949). The variables measured were numbers of sporangia per leaf and numbers of sporangia per square centimeter of lesion area. Data were $\log _{10}$-transformed after adding one to each data point to avoid taking the log of zero, prior to analysis, to improve normality of residuals, reduce skewness, and equalize variances (which were found to be a function of the weekly means) (Sokal and Rohlf 1995). Continuous moisture data were also analyzed by regression analysis in SAS (SAS Institute, Inc. 2008) and Minitab 17 Statistical Software (Minitab, Inc. 2010) to examine the relationship between sporangia production and time (weeks). To determine the relationship between $P$. ramorum sporangia production on Rhododendron 'Cunningham's White' over time (weeks), we analyzed the $\log _{10}$-transformed data using the Fitted Line Plot procedure in Minitab, which performs regression with linear and polynomial (second or third order) terms of a single predictor variable and plots a regression line through the data. Polynomial regression was used to model curvature in the relationship between the response variable $(y=$ sporangia production) and predictor variable $(x=$ weeks) by extending the simple linear regression model to include $x^{2}$ and $x^{3}$ as predictors. This method fits a nonlinear relationship between the value of $x$ and the corresponding conditional mean of $y$, and has often been used to describe nonlinear phenomena in biological science (Sokal and Rohlf 1995).

\section{RESULTS}

Sporangia production in continuous moisture. ANOVA showed that significant differences $(P<0.001)$ existed between experiment 1 and experiment 2; therefore, the two experiments are presented individually (Fig. 1). In the first experiment, sporangia were collected from three plants over a 22 -week period, one plant over a 19-week period, one plant over a 13 -week period, and one plant over a 12-week period. Sporangia levels, however, declined rapidly, falling from a high of 4,648 sporangia/leaf during week 2 to 84 sporangia/week during week 7 . In the second experiment, $P$. ramorum continued to produce sporangia for up to 22 weeks, except that no sporangia were collected at weeks 13 and 19. One plant produced sporangia over a 22-week period (with the exception of 13 and 19 weeks), one plant over a 17-week period, two plants over a 10-week period, and one plant over a 9-week period. Sporangia levels declined sharply by 6 weeks, with levels falling to an average of 75 sporangia/leaf (Fig. 1). As production declined, sporangia production became sporadic, alternating between counts of 0 to 11 from one sampling date to the next. By the time sporangia were no longer collected from individual plants, the infection had moved from the leaves into the petioles and then into the stems. Also, the majority of leaves had been shed by this time and were deteriorating in the screens due to the continuously moist conditions.

For experiment 1 , significant $(P<0.001)$ linear and quadratic effects were observed, whereas cubic effects were not significant $(P=0.293)$. The best-fitting regression equation was $\log _{10}$ (sporangia/leaf +1$)=4.355-0.4093$ week +0.009933 week $^{2}$, with an adjusted $R^{2}$ of $86.9 \%$. For experiment 2 , linear, quadratic, and cubic effects were all significant $(P<0.001)$ and the best-fitting equation was $\log _{10}$ (sporangia/leaf +1$)=5.330-0.8325$ week + 0.04305 week $^{2}-0.000729$ week $^{3}$.with an adjusted $R^{2}$ of $86.0 \%$. Even though experiment means varied from one another in the ANOVA analysis, we thought it would be of value to calculate a regression equation for total sporangia per leaf over both experiments, in effect averaging out the differences between the experiments. Thus, for both experiments combined, the best-fitting equation was $\log _{10}($ sporangia/leaf +1$)=4.882-0.6383$ week +0.02819 week $^{2}$ -0.000410 week $^{3}$, with an adjusted $R^{2}$ of $84.3 \%$.

Sporangia production following exposure to varied RH levels. ANOVA (data not shown) indicated that the method used 
to produce diseased leaves (inoculation with sporangia followed by incubation in dew chambers or wound inoculation with colony plugs followed by incubation in humid chambers) was not a statistically significant factor $(P=0.3139$ for sporangia per leaf and $P=0.111$ for sporangia per square centimeter of infected leaf tissue); therefore, data from experiments 1 and 2 were combined with data from experiments 3 and 4 for analysis. Sporangia production showed a decreasing trend over the 9 weeks of the experiment when the experiments were combined (Figs. 2 and 3).

We found that the highest levels of sporangia production by $P$. ramorum occurred on detached leaves that had been maintained in an atmosphere of 96.2 or $100 \%$ RH (Figs. 2 and 3). When detached leaves were maintained at $100 \% \mathrm{RH}$ for up to 9 weeks, average sporangia production ranged from a high of 14,097 sporangia/ leaf $\left(1,202\right.$ sporangia/ $\left./ \mathrm{cm}^{2}\right)$ produced at week 2 , decreasing to a mean of 22 sporangia/leaf (1.277 sporangia/ $\mathrm{cm}^{2}$ ) at week 9 (Figs. 2 and 3). When leaves were held at $96.2 \% \mathrm{RH}$, leaves supported sporangia production by $P$. ramorum for 8 consecutive weeks, with a mean of 7,909 sporangia/leaf $\left(866\right.$ sporangia/ $\left.\mathrm{cm}^{2}\right)$ at week 1 , and a mean of 2.7 sporangia/leaf $\left(0.16\right.$ sporangia/ $\left.\mathrm{cm}^{2}\right)$ at week 8 (Figs. 2 and 3$)$. When detached leaves were maintained at $84.5 \% \mathrm{RH}$, leaves supported sporangia production for 4 of the first 5 weeks, with a mean of 4,747 sporangia/leaf (605 sporangia/ $\left./ \mathrm{cm}^{2}\right)$ at week 1 , decreasing to a mean of 0.111 sporangia/leaf $(0.0454$ sporangia/ $\mathrm{cm}^{2}$ ) at week 5. Fewer than 10 sporangia were collected from weeks 4 through 9 in the $84.5,74.9$, and $56.2 \%$ RH treatments. Not only did intensity of sporulation on infected leaves decline over time but also the numbers of sporulating leaves declined as well. Thus, over increasing time, detached leaves showed decreased ability to support $P$. ramorum sporulation even at favorable levels of $\mathrm{RH}$. ANOVA for sporangia per leaf (Table 2) and sporangia per square centimeter (Table 3) showed that experiment was not a significant factor $(P=0.086$ for sporangia per leaf and 0.172 for sporangia per square centimeter of infected leaf tissue) but that humidity treatments had a major effect $(P<0.001$ for both sporangia per

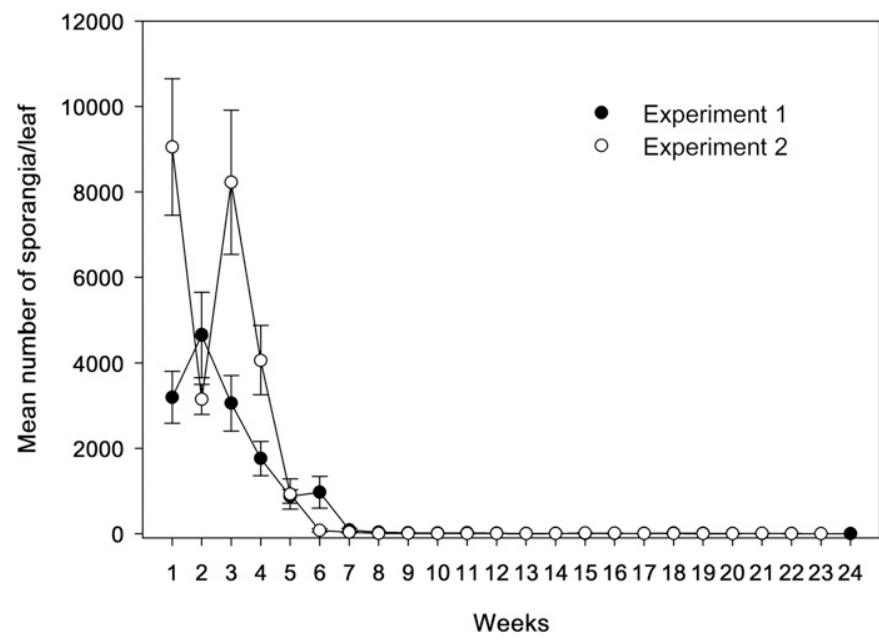

Fig. 1. Duration of sporangia production in two experiments by Phytophthora ramorum on infected, whole plants of Rhododendron 'Cunningham's White' in continuous moisture. Infected plants were removed from dew chambers and transferred to a mist tent; each plant was propped on its side so that one group of diseased leaves extended over a 20.3-cm-diameter screen made from PVC pipe and $15-\mu \mathrm{m}$ mesh size nitrile fabric. All other leaves were removed. Fogging nozzles were programmed to activate for $12 \mathrm{~s}$ every 4 min to maintain leaf wetness and facilitate movement of dehisced sporangia from diseased leaves into the screens. Sporangia were rinsed from the collection screens with a squirt bottle of tap water into 50-ml centrifuge tubes, and the number of sporangia in three 1 -ml aliquots was determined through direct counting at $\times 40$ magnification under darkfield optics on a dissecting microscope. Bars represent standard errors. For experiment 1 , the best-fitting regression equation was $\log _{10}$ (sporangia/leaf + 1) $=4.355-0.4093$ week +0.009933 week $^{2}$ whereas, for experiment 2 , the bestfitting equation was $\log _{10}($ sporangia/leaf +1$)=5.330-0.8325$ week +0.04305 week ${ }^{2}-0.000729$ week $^{3}$. leaf and sporangia per square centimeter of infected leaf tissue). The effect of week of exposure was also significant $(P<0.001)$ for both sporangia per leaf (Table 2 ) and sporangia per square centimeter of infected leaf tissue (Table 3 ). We also observed a significant treatment-week interaction for both variables, which indicates that the effects of the various RH treatments did not show consistent trends over the 9 weeks of the experiments. Because the treatments were varied, ranging from controlled $\mathrm{RH}$ levels in moist chambers to greenhouse bench treatment to $10 \mathrm{~h}$ of dew treatment, this is not unexpected. Use of the log transformation increased fit of the model from an $R^{2}$ of 21.8 to $74.7 \%$ for sporangia per leaf and from 26.2 to $73.2 \%$ for sporangia per square centimeter of leaf tissue. It also greatly improved the normality of the data and reduced skewness (data not shown).

Diseased leaves were also collected from inoculated rhododendron plants that were maintained on a greenhouse bench for 9 weeks with dry foliage. Sporangia production by $P$. ramorum on greenhouse rhododendrons was low compared with that on detached leaves incubated in chambers at 100 and $96.2 \% \mathrm{RH}$ for the first 6 weeks of the experiments, presumably from desiccation of diseased leaf tissue. Sporangia production on greenhouse plants lasted for all 9 weeks, ranging from 109.5 sporangia/leaf $\left(32.4\right.$ sporangia $\left./ \mathrm{cm}^{2}\right)$ at week 1 to
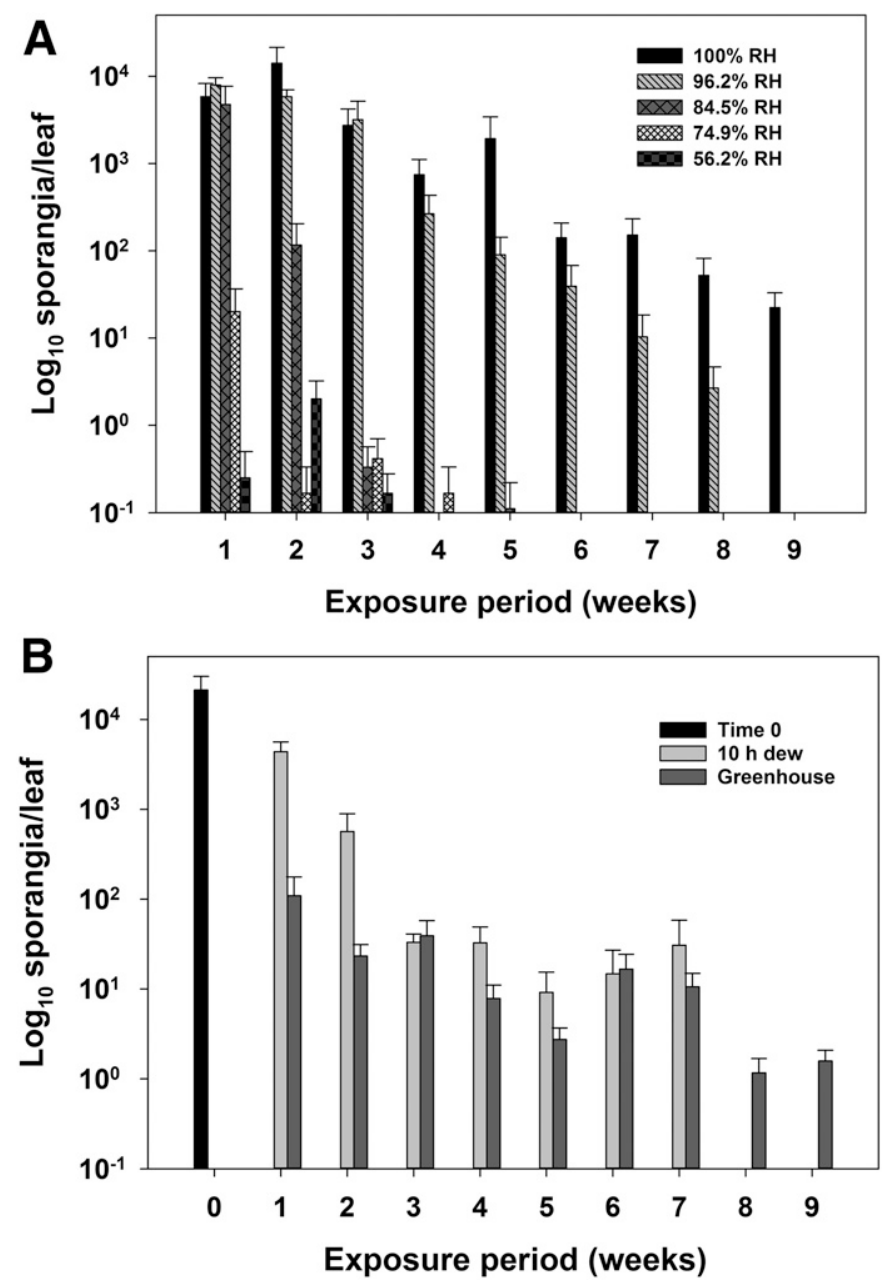

Fig. 2. Sporulation (mean sporangia per leaf) by Phytophthora ramorum on infected, detached leaves of Rhododendron 'Cunningham's White' following exposure to differing relative humidity levels. A, Data for infected, detached leaves held at the five relative humidity (RH) levels produced in humidity chambers which contained glycerin solutions to produce levels of 100, 96.2, 84.5, 74.9, and 56.2\% RH. B, Data for infected leaves produced on whole plants at time 0 , for those subjected to $10 \mathrm{~h}$ of dew in a mist chamber, and for those maintained in a greenhouse with dry foliage. Bars represent standard errors. 
1.58 sporangia/leaf (0.852 sporangia/ $\left.\mathrm{cm}^{2}\right)$ at week 9 (Figs. 2 and 3). However, some fluctuation in sporangia numbers was observed from week to week and it was not a steady decline. When plants were maintained in a mist tent in a climate-controlled greenhouse cubicle and subjected to simulated dew for $10 \mathrm{~h}$ nightly, sporulation levels were significantly $(P=0.05)$ higher at weeks 1 and 2 , respectively, than for leaves collected from greenhouse plants, but sporulation levels were not significantly different for weeks 3 through 7 . Mean sporulation levels under simulated dew conditions were 4,377 sporangia/leaf and 2,121 sporangia/ $\mathrm{cm}^{2}$ at week 1 , declining to 30.8 sporangia/leaf and 7.93 sporangia/ $\mathrm{cm}^{2}$ at week 7 .

The percentage of diseased leaves to support sporulation by $P$. ramorum was analyzed following exposures at constant $\mathrm{RH}$ over time (Table 4). ANOVA showed that RH treatment and exposure period (weeks) were both highly significant factors $(P<0.001)$, as was the RH treatment-week interaction. After 9 weeks, $41.7 \%$ of detached leaves held in $100 \% \mathrm{RH}$ and $50 \%$ of attached leaves collected from greenhouse plants still supported sporulation but detached leaves subjected to no other treatments did (Table 4). For diseased leaves held at $96.2 \% \mathrm{RH}$, spores were collected from 83,67 , and $33 \%$ of leaves after 4,5 , and 6 weeks of incubation, respectively.

Leaf hydration. Combined leaf hydration values (percent leaf moisture) from experiments 2 and 4 are displayed in Figure 4. When
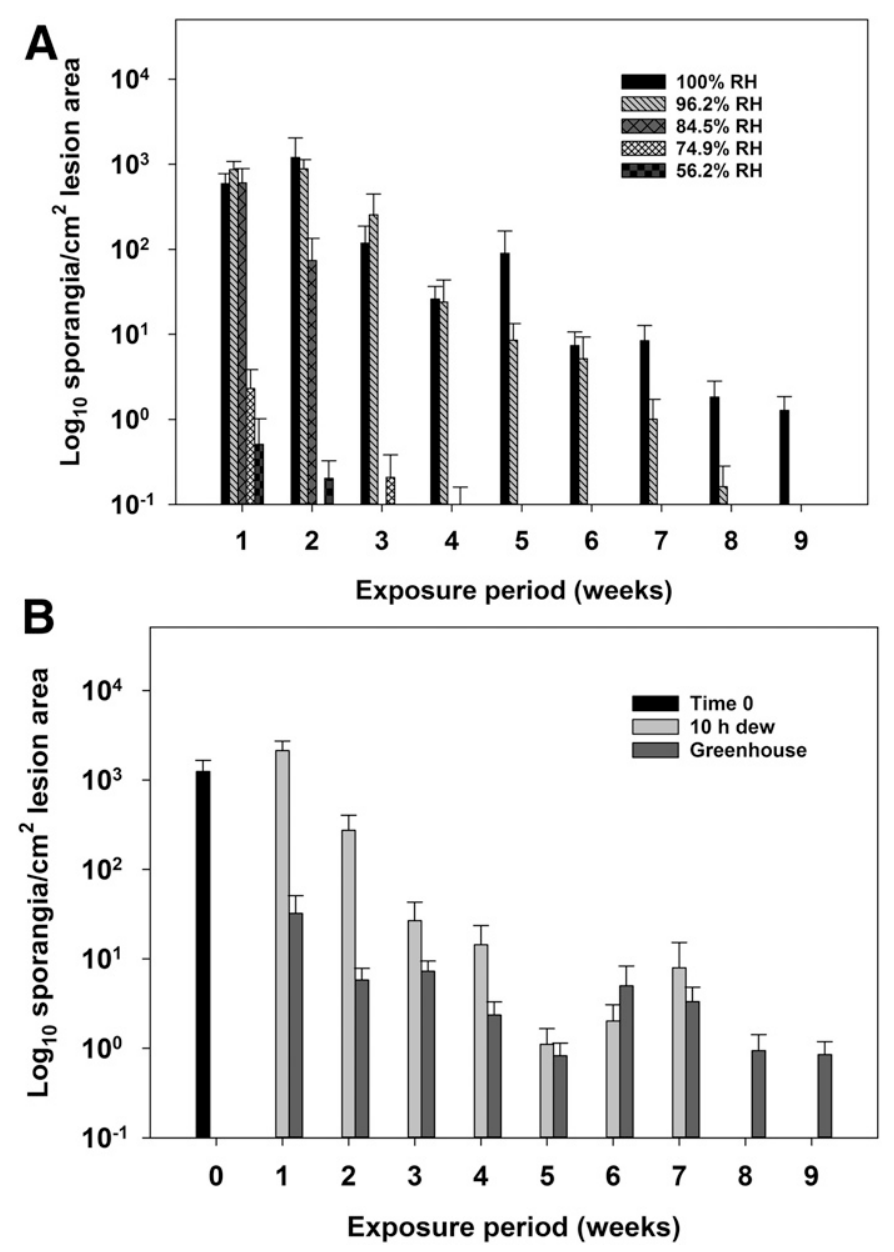

Fig. 3. Sporulation (mean sporangia per square centimeter of infected leaf tissue) by Phytophthora ramorum on infected, detached leaves of Rhododendron 'Cunningham's White' following exposure to differing relative humidities (RH). A, Data for infected, detached leaves held at the five RH levels produced in humidity chambers which contained glycerin solutions to produce levels of $100,96.2,84.5,74.9$, and $56.2 \%$ RH. B, Data for infected leaves produced on whole plants at time 0 , for those subjected to $10 \mathrm{~h}$ of dew nightly in a greenhouse mist chamber, and for those maintained in a greenhouse with dry foliage. Bars represent standard errors. detached, diseased leaves were held in humidity chambers, leaf moisture for all RH levels declined during the first week. Detached leaves incubated in an atmosphere of $100 \% \mathrm{RH}$ had the highest moisture content and the least fluctuation in leaf moisture levels over the 9 weeks. Lesion expansion was observed only on detached leaves held in an atmosphere of $100 \% \mathrm{RH}$, with leaves becoming completely blackened within a few weeks. Leaves subjected to the greenhouse treatment also showed consistent leaf moisture levels over the 9 weeks, although they were the lowest levels observed (Fig. 4).

As RH within the chambers decreased, so did the moisture content of leaves within the chambers. Within hours of removal from dew, diseased tissue on attached leaves was observed to be very dry whereas healthy leaf tissue remained hydrated. Lesion expansion was not observed on plants held in the greenhouse when foliage remained dry. When plants were subjected to $10 \mathrm{~h}$ of mist nightly to simulate dew, diseased leaf tissue also dried out, with many leaves abscissing. Some lesion expansion was observed, along with petiole infection leading to dieback in some cases. However, sporangia were not collected in screens placed under the canopy in the mist tent, and there was no evidence of disease spreading through splashing or dripping of spores. Disease was limited to those branches whose leaves had been inoculated with plugs. Leaves removed from plants maintained with dry foliage on a greenhouse bench contained more moisture than leaves removed from plants that were subjected to $10 \mathrm{~h}$ of mist nightly to simulate dew (Fig. 4). The detrimental effect of lower moisture content was demonstrated by the cessation of sporulation by week 8 at RH levels below $96.2 \%$, whereas 40 to $50 \%$ of leaves collected from greenhouse plants supported sporulation on week 8 and 9 (Table 4).

To examine the relationship between sporulation and leaf moisture content, sporangia per leaf was plotted as a function of percent leaf moisture for experiments 2 and 4 combined (Fig. 5). To fulfill the assumptions underlying the regression model, improve normality and goodness of fit of the model, and reduce skewness, data for sporangia per leaf was $\log _{10}$-transformed after adding 1 to each observation to prevent taking the log of zero. The resulting regression equation was $\log _{10}($ sporangia/leaf +1$)=-0.7476+0.04532$ (percent leaf moisture), and had an adjusted $R^{2}$ of $47.7 \%$. From analyzing Figure 5, it is apparent that approximately $17 \%$ leaf moisture is the lowest value that can support sporangia production by $P$. ramorum.

$P$. ramorum was recovered from all detached leaves that had been incubated for up to 9 weeks in atmospheres of 100 and $96.2 \%$ humidity. The percentage of these leaves that supported sporangia production, obtained by averaging the percentages observed at each of the 9 weeks (Table 4), was 83 and $60 \%$, respectively. There was

TABLE 2. Analysis of variance table for numbers of sporangia per leaf produced by Phytophthora ramorum on detached, infected leaves of Rhododendron 'Cunningham's White' held at different relative humidity levels for 9 weeks ${ }^{\mathrm{y}}$

\begin{tabular}{lrrr}
\hline Source & $\mathrm{df}^{\mathrm{z}}$ & $F$ value & $P$ value \\
\hline Experiment & 3 & 2.21 & 0.086 \\
Treatment & 6 & 143.32 & $<0.001$ \\
Week & 8 & 91.05 & $<0.001$ \\
Treatment $\times$ week & 48 & 10.86 & $<0.001$ \\
Error & 608 & $\ldots$ & $\ldots$ \\
Lack of fit & 159 & 2.60 & $<0.001$ \\
Pure error & 449 & $\ldots$ & $\ldots$ \\
Total & 673 & $\ldots$ & $\ldots$ \\
\hline
\end{tabular}

y Diseased, detached leaves were incubated in humidity chambers constructed from Rubbermaid plastic storage containers for up to 9 weeks. Glycerin solutions were added to each container to produce relative humidity levels of $100,96.2,84.5,74.9$, and $56.2 \%$. To assess sporangia production, leaves were removed at weekly intervals and placed in a mist tent for $72 \mathrm{~h}$, which allowed movement of dehisced sporangia into collection screens. Screens were then rinsed into 50-ml centrifuge tubes and sporangia counted under a dissecting microscope.

$\mathrm{z}$ Degrees of freedom. 
no recovery of $P$. ramorum from leaves incubated at $84.5 \%$ RH that did not support sporangia production. However, there were 11 leaves that had been held at 74.9 and $56.2 \%$ RH for 1 to 4 weeks from which a small number of sporangia $(<15$ per leaf) were collected; however, P. ramorum was not recovered on PARPH-V8.

Enhanced recovery. In a subsequent experiment designed to confirm these recovery results, lesions from diseased leaves were plated on PARPH-V8; then, leaves were incubated in moistened vermiculite at $4^{\circ} \mathrm{C}$ for 2 months and plated again. Recovery was enhanced by an extended incubation period at $4^{\circ} \mathrm{C}$ when leaves had been incubated in an atmosphere of 74.9 or $56.2 \%$ RH for 7 days. By 14 days, the next sampling date, there was no recovery either pre- or postcold storage. When diseased leaves had been incubated for 14 days in an atmosphere of $84.5 \% \mathrm{RH}$, recovery was enhanced by cold storage. By 21 days, the next sampling date, there was no recovery either pre- or postcold storage. Thus, it appears that, when $P$. ramorum could not be isolated from leaves following a 72-h period in a mist tent to assess sporangia production, it was a good indication that $P$. ramorum did not survive in detached leaves held at low RH values for an extended period.

\section{DISCUSSION}

We performed experiments to determine the ability of $P$. ramorum to produce sporangia on intact plants of Rhododendron 'Cunningham's White' in continuous moisture and also on detached leaves following incubation for up to 9 weeks at various levels of constant RH. Tooley

TABLE 3. Analysis of variance table for numbers of Phytophthora ramorum sporangia per square centimeter of infected lesion area on detached leaves of Rhododendron 'Cunningham's White' held at different relative humidity levels for 9 weeks $^{y}$

\begin{tabular}{lrrc}
\hline Source & $\mathrm{df}^{z}$ & $F$ value & $P$ value \\
\hline Experiment & 3 & 1.67 & 0.172 \\
Treatment & 6 & 90.78 & $<0.001$ \\
Week & 8 & 106.63 & $<0.001$ \\
Treatment $\times$ week & 48 & 12.65 & $<0.001$ \\
Error & 608 & $\ldots$ & $\ldots$ \\
Lack of fit & 159 & 2.88 & $<0.001$ \\
Pure error & 449 & $\ldots$ & $\ldots$ \\
Total & 673 & $\ldots$ & $\ldots$ \\
\hline
\end{tabular}

y Diseased, detached leaves were incubated in humidity chambers constructed from Rubbermaid plastic storage containers for up to 9 weeks. Glycerin solutions were added to each container to produce relative humidity levels of $100,96.2,84.5,74.9$, and $56.2 \%$. To assess sporangia production, leaves were removed at weekly intervals and placed in a mist tent for $72 \mathrm{~h}$, which allowed movement of dehisced sporangia into collection screens. Screens were then rinsed into 50-ml centrifuge tubes and sporangia counted under a dissecting microscope.

${ }^{\mathrm{z}}$ Degrees of freedom. and Browning (2015) previously assessed the effects of temperature and moisture period required for first occurrence of sporulation on detached leaves of Rhododendron 'Cunningham's White', and found that sporangia were first collected from leaves following a 24-h incubation period at $100 \% \mathrm{RH}$. In the present study, we observed that, in continuous moisture, $P$. ramorum sporangia on infected leaves could be collected from infected Rhododendron 'Cunningham's White' leaves for up to 22 weeks postinoculation. The relationship between sporangia production and time (weeks) was best described by polynomial equations that included significant higher-order polynomial terms (e.g., quadratic and cubic).

The 22 weeks over which we observed sporangia production represents a long period of spore production compared with some other oomycete and fungal plant pathogens. For example, Gigot et al. (2009) found that, following a 6-week storage period, the number of potato tuber lenticels supporting $P$. infestans sporulation was very low on inoculated, buried tubers, and sporulation was no longer detected on tuber lenticels after 12 weeks of storage. For the rust fungus Puccinia recondita f. sp. triticina on barley (Hordeum vulgare L.), Mehta and Zadoks (1970) found the longest observed sporulation period to be 65 days. And Rossi et al. (2009) found that conidia of Fusarium verticillioides were produced on inoculated cornstalk residues for more than 30 days.

Our studies showed that, during the first 4 weeks of continuous moisture, there was no significant $(P=0.05)$ reduction in Phytophthora ramorum sporangia production, showing that extended moist conditions such as are present during the rainy season in California (Davidson et al. 2005, 2008, 2011), and perhaps during periods of extended fog, should allow $P$. ramorum to sporulate at high levels, thus producing large amounts of inoculum capable of initiating or maintaining severe epidemics.

Villareal et al. (1981) used length of the sporulation period for Pyricularia oryzae on rice (Oryza sativa) as a criterion in an attempt to describe total sporulation capacity and considered it a component of slow-leaf-blast infection in certain cultivars. Rouse et al. (1980) assessed sporulation capacity and longevity of Erysiphe graminis $\mathrm{f}$. sp. tritici as a component of rate-reducing resistance in four wheat cultivars. In addition, Asher and Thomas (1984) found that resistant varieties of spring barley (H. vulgare L.) were found to yield only one-third as many spores of $E$. graminis compared with susceptible varieties. Shorter sporulation period is also considered a component of partial resistance to Puccinia hordei in barley (H. vulgare L.) (Parlevliet and Van Ommeren 1975).

Tooley et al. (2011) assessed the sporangia production capacity of Phytophthora ramorum on northern red oak and chestnut oak, and found that an average of 259 sporangia $/ \mathrm{cm}^{2}$ of lesion area was produced on chestnut oak (Quercus prinus), while 2,294 sporangia/ $\mathrm{cm}^{2}$ of lesion area was produced on Northern red oak (Q. rubra). With detached leaves of Camellia spp., Linderman and Davis (2007) found that sporangia production ranged from $<100$ to $>900$ sporangia/ $/ \mathrm{cm}^{2}$ of

TABLE 4. Percentage of leaves on which Phytophthora ramorum produced sporangia following exposure to different relative humidities (RH) in four experiments ${ }^{\mathrm{w}}$

\begin{tabular}{|c|c|c|c|c|c|c|c|c|c|}
\hline \multirow[b]{2}{*}{ Treatment $^{\mathrm{x}}$} & \multicolumn{9}{|c|}{ Exposure period (weeks) } \\
\hline & 1 & 2 & 3 & 4 & 5 & 6 & 7 & 8 & 9 \\
\hline $100 \% \mathrm{RH}$ & $100 \mathrm{a}$ & $100 \mathrm{a}$ & $100 \mathrm{a}$ & $100 \mathrm{a}$ & $100 \mathrm{a}$ & $66.7 \mathrm{a}$ & $83.3 \mathrm{a}$ & $58.3 \mathrm{a}$ & $41.7 \mathrm{ab}$ \\
\hline $96.2 \% \mathrm{RH}$ & $100 \mathrm{a}$ & $100 \mathrm{a}$ & $100 \mathrm{a}$ & $83.3 \mathrm{a}$ & $66.7 \mathrm{ab}$ & $33.3 \mathrm{abc}$ & $25.0 \mathrm{ab}$ & $33.3 \mathrm{a}$ & $0 \mathrm{~b}$ \\
\hline $84.5 \% \mathrm{RH}^{\mathrm{y}}$ & $100 \mathrm{a}$ & $77.8 \mathrm{ab}$ & $22.2 \mathrm{~b}$ & $0 \mathrm{bc}$ & $11.1 \mathrm{bc}$ & $0 \mathrm{bc}$ & $0 \mathrm{~b}$ & $0 \mathrm{a}$ & $0 \mathrm{ab}$ \\
\hline $74.9 \% \mathrm{RH}$ & $58.3 \mathrm{ab}$ & $8.33 \mathrm{~d}$ & $16.7 \mathrm{~b}$ & $8.3 \mathrm{c}$ & $0 \mathrm{c}$ & $0 \mathrm{c}$ & $0 \mathrm{~b}$ & $0 \mathrm{a}$ & $0 \mathrm{~b}$ \\
\hline $56.2 \% \mathrm{RH}$ & $8.3 \mathrm{~b}$ & $25.0 \mathrm{~cd}$ & $16.7 \mathrm{~b}$ & $0 \mathrm{c}$ & $0 \mathrm{c}$ & $0 \mathrm{c}$ & $0 \mathrm{~b}$ & $0 \mathrm{a}$ & $0 \mathrm{~b}$ \\
\hline $10 \mathrm{~h}$ of dew $\mathrm{z}$ & $100 \mathrm{a}$ & $100 \mathrm{ab}$ & $100 \mathrm{a}$ & $83.3 \mathrm{a}$ & $50.0 \mathrm{abc}$ & $66.7 \mathrm{ab}$ & $33.3 \mathrm{a}$ & $0 \mathrm{a}$ & $0 \mathrm{ab}$ \\
\hline $\mathrm{GH}$ & $66.7 \mathrm{ab}$ & $58.3 \mathrm{bc}$ & $91.7 \mathrm{a}$ & $66.7 \mathrm{ab}$ & $66.7 \mathrm{ab}$ & $58.3 \mathrm{a}$ & $41.7 \mathrm{ab}$ & $41.7 \mathrm{a}$ & $50.0 \mathrm{a}$ \\
\hline
\end{tabular}

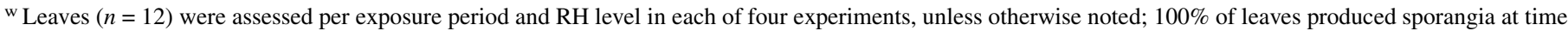
0 . Means within a column followed by the same letter do not differ significantly by Tukey's test, $P=0.05$. Letters reflect means comparisons performed using arcsin square root-transformed data.

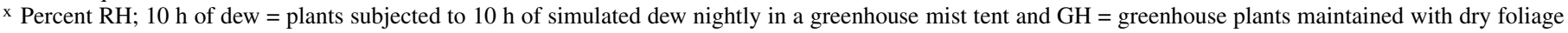
$(43.3 \pm 9.2 \% \mathrm{RH})$.

y Leaves assessed: $n=9$.

z Leaves assessed: $n=6$. 
lesion area. A comparatively small number of sporangia (average of 19/leaf) were observed on coast live oak (Q. agrifolia) leaves infected with $P$. ramorum by artificial inoculation with agar plugs (Vettraino et al. 2008). Denman et al. (2006) reported a range of sporangia production observed in detached-leaf tests performed on U.K. forest species but counts are expressed on a log scale without mention of the unit of measurement (i.e., sporangia per leaf, per lesion area, and so on), making it difficult to compare results with other studies. Moralejo et al. 2006 measured sporangia numbers produced by five $P$. ramorum isolates on artificially inoculated detached leaves of Mediterranean woody species and observed ranges of 21 to 300 sporangia $/ \mathrm{cm}^{2}$ for Arbutus unedo, 33 to 252 sporangia $/ \mathrm{cm}^{2}$ for Viburnum tinus, 297 to 1,214 sporangia $/ \mathrm{cm}^{2}$ for Rhamnus alaternus, 7 to 1,680 sporangia/ $\mathrm{cm}^{2}$ for Pistacia lentiscus, and 61 to 1,154 sporangia/ $\mathrm{cm}^{2}$ for Lonicera implexa. Hüberli et al. (2008) reported a range of sporangia numbers per leaf for $18 \mathrm{New}$ Zealand plant species artificially inoculated with Phytophthora ramorum zoospores and incubated for 6 days at $19^{\circ} \mathrm{C}$ in darkness. Numbers ranged from 0 to 65.3 sporangia/leaf, and they reported 23.5 sporangia/leaf for Rhododendron 'Cunningham's White', which is substantially lower than reported in the present study. The low numbers could be due to the method used for collecting sporangia from infected leaves, which involved scraping leaf surfaces into microtiter plate wells prior to counting. Tooley and Browning (2009) assessed the sporulation capacity of $P$. ramorum on 25 plant species constituting a portion of the understory in Eastern U.S. forests, and found that sporangia production varied considerably among plant species, ranging from a high of 2,001 sporangia $/ \mathrm{cm}^{2}$ lesion area produced on Robinia pseudoacacia to a low of 36 sporangia $/ \mathrm{cm}^{2}$ produced on Myrica pennsylvannica. A value of 650 sporangia/ $\mathrm{cm}^{2}$ was observed for Rhododendron 'Cunningham's White', which was very close to the value of 591 sporangia $/ \mathrm{cm}^{2}$ lesion area observed in the present study after 1 week at $100 \% \mathrm{RH}$. Perhaps, in the future, such measures of sporulation could be used to assess levels of resistance in host species, knowledge which could be used in making planting or eradication recommendations in landscapes and nurseries to limit spread of the pathogen.

Incubation in dew chambers for 5 to 7 days subjects plants to extremely wet, moist conditions. Within hours of removal from dew, the diseased leaf tissue becomes very dry, turning a pale gray color, compared with the surrounding tissue. We have not observed lesion expansion when plants are subsequently maintained on a greenhouse bench with dry foliage. To eliminate the possibility that the extreme desiccation of diseased leaf tissue is related to an extended period in dew chambers, we utilized an alternate inoculation strategy in experiments 3 and 4, in which inverted plugs were placed over a small wound in each leaf. Plants were then maintained in an atmosphere of high humidity but leaves remained dry. We observed the diseased foliage to undergo the same extreme drying following removal from humid chambers as from dew chambers. In addition, there was no statistical difference in the percentage of leaves to support sporangia production regardless of incubation method. Leaves on rhododendron plants maintained with dry foliage in a greenhouse (average RH of $43.3 \pm 9.2 \%$ ) had higher hydration levels than did leaves from plants maintained in a mist tent in a greenhouse cubicle and subjected to $10 \mathrm{~h}$ of mist nightly to simulate dew (Fig. 4). Foliage was visibly drier on plants held in the mist tent, and many diseased leaves abscissed. Based on these results and earlier observations, it appears that wetting and drying cycles are detrimental to the ability of $P$. ramorum to sporulate and survive in leaf tissue. In

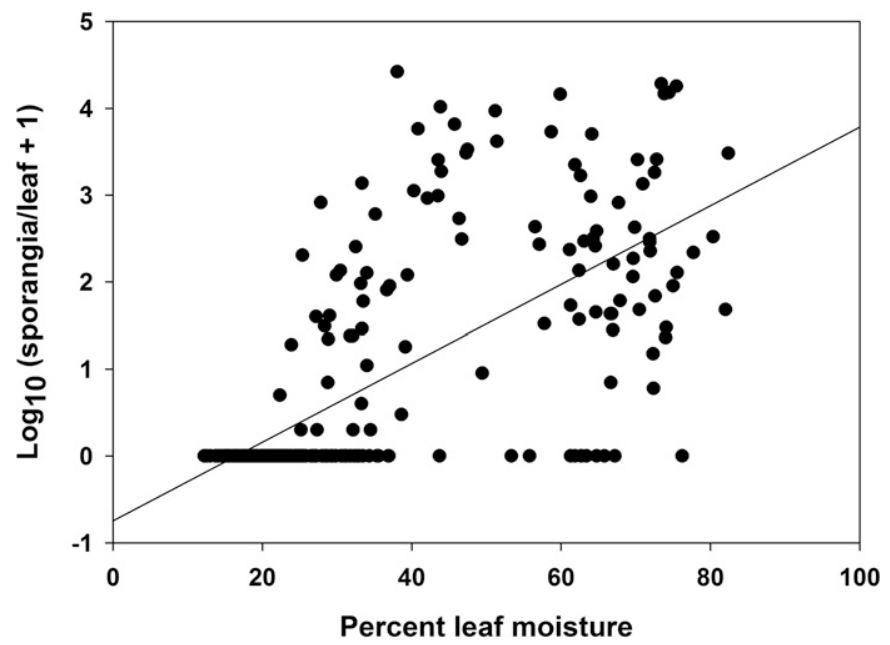

Fig. 5. Scatter plot and corresponding regression line describing the relation between sporangia production and leaf moisture content for Phytophthora ramorum isolate Cam 5C on Rhododendron 'Cunningham's White'. The regression equation was $\log _{10}($ sporangia/leaf +1$)=-0.7476+0.04532$ (percent leaf moisture), with an adjusted $R^{2}$ of $47.7 \%$. Data for sporangia per leaf in experiments 2 and 4 were $\log _{10}$-transformed after adding 1 to each observation to prevent taking the $\log$ of zero.

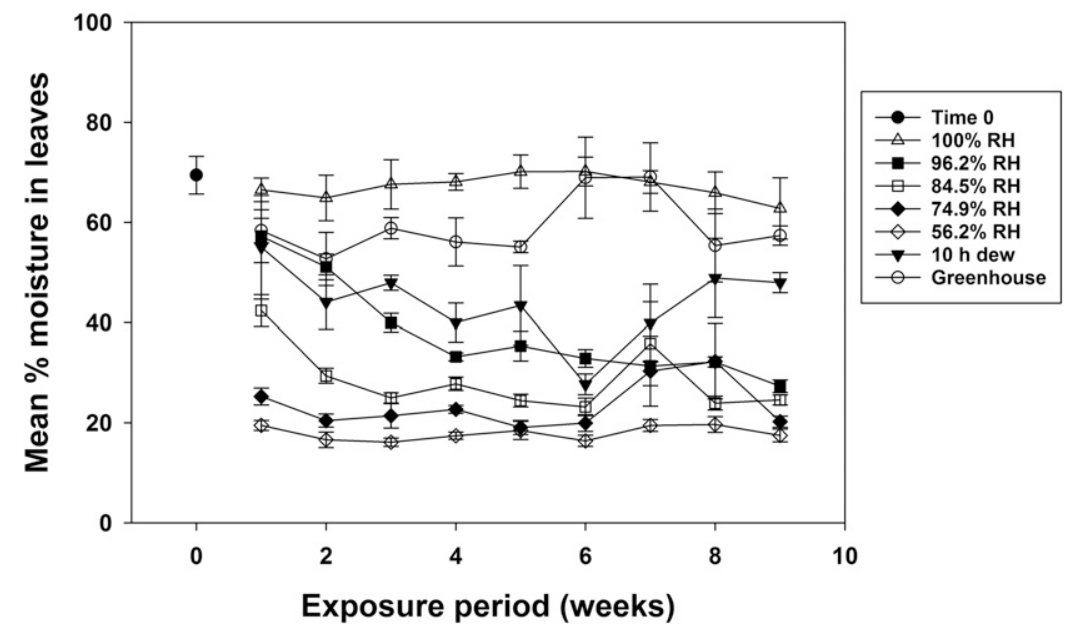

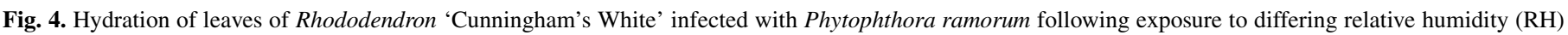

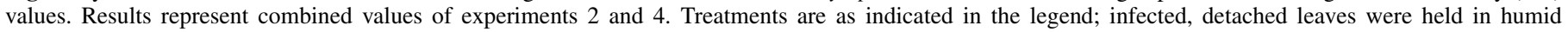

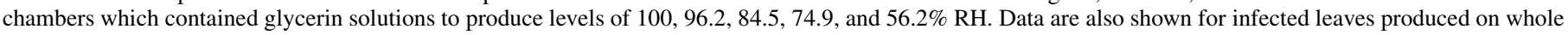

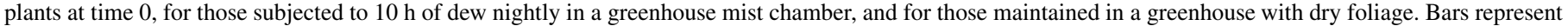
standard errors. 
addition, no sporangia were collected in screens placed under the canopy; therefore, it appears that the period of leaf wetness resulting from the deposition of dew at night may be too brief to support sporangia production by $P$. ramorum, at least under the conditions experienced here. Thus, in general, with increasing time, detached leaves of Rhododendron 'Cunningham's White' showed decreased ability to support $P$. ramorum sporulation, even when incubated at favorable levels of RH.

When maintained at suboptimal levels of RH for up to 9 weeks followed by a period of high $\mathrm{RH}$ to induce sporangia production, $P$. ramorum showed reduced levels of sporangia production compared with production when maintained at $100 \% \mathrm{RH}$.

Sporulation levels by $P$. ramorum were initially much higher on leaves collected from greenhouse plants subjected to $10 \mathrm{~h}$ of dew nightly than greenhouse plants maintained with dry foliage; however, spores were collected over a longer period of time (9 versus 7 weeks) when foliage remained dry. Diseased leaf tissue was also observed to dry out, with lesions becoming pale gray and many leaves abscissing.

The effects of desiccation of host plant material on sporulation or growth of other plant pathogens have also been assessed. For Colletotrichum coccodes, Dillard (1989) observed that conidial germination dropped substantially after infected tomato (Solanum lycopersicum) fruit were exposed to 2,8 , or $24 \mathrm{~h}$ of drying at room temperature and 55 to $57 \%$ RH. For Botrytis squamosa (Alderman and Lacy 1984), sporulation occurred within 2 days when dried, colonized leaves were incubated under moist conditions. Bean flowers colonized by Sclerotinia sclerotiorum and dried for $96 \mathrm{~h}$ took approximately three times longer to achieve $100 \%$ white mold incidence compared with those dried for $24 \mathrm{~h}$ (Harikrishnan and del Rio 2006).

Survival of $P$. ramorum in desiccated leaf tissue has implications for understanding sudden oak death epidemiology. P. ramorum could, for example, survive in leaf tissue during the drier part of the season and have the potential for renewed sporulation when moist conditions return. We determined in these studies that, for Rhododendron 'Cunningham's White', approximately $17 \%$ leaf moisture is the lowest value that can support sporangia production by $P$. ramorum but this will likely vary for different host species. It has been observed that $P$. ramorum is difficult to recover from mixed evergreen forests in California during the hot, dry summer months (Davidson et al. $2005,2008,2011$ ), presumably due to desiccation of leaves of some of its primary hosts. Thus, our studies bear on the potential for inoculum in leaf tissue (for leaves remaining on trees as well as detached leaves forming part of the leaf litter layer) to continue to sporulate following periods of drying at low $\mathrm{RH}$ values. Were host plants able to produce fresh inoculum following dry periods, new epidemics in periods following the dry summer period would not have to rely on external inoculum sources for initiation, because sporangia could be produced from dormant lesions.

Knowledge of specific humidity levels that preclude subsequent sporangia formation by $P$. ramorum will also prove useful in terms of management if humidity levels in commercial greenhouses, for example, could be lowered to levels that do not allow subsequent $P$. ramorum sporulation to occur. Such recommendations could, in addition, contribute toward development of best management practices (Griesbach et al. 2011; Suslow 2008). Knowledge of the effects of drying on subsequent sporulation of $P$. ramorum during periods of high $\mathrm{RH}$ could also be used to develop or improve predictive models, as has been done with Peronospora destructor, which causes downy mildew of onion (Friedrich et al. 2003; Gilles et al. 2004). The models MILLIONCAST as well as DOWNCAST are both based on prediction of $P$. destructor sporulation based on parameters which include RH periods (Gilles et al. 2004; Hildebrand and Sutton 1984; Jesperson and Sutton 1987). In the future, Phytophthora ramorum sporulation parameters should be determined for additional host species, both major forest hosts as well as additional understory hosts, to determine whether there are host-specific effects that determine sporulation levels in response to $\mathrm{RH}$ and other environmental conditions. The effect of periods of wetting and drying on $P$. ramorum sporulation should also be examined in future experiments.

\section{ACKNOWLEDGMENTS}

Mention of trade names or commercial products in this publication is solely for the purpose of providing specific information and does not imply recommendation or endorsement by the U.S. Department of Agriculture. USDA is an equal opportunity provider and employer.

\section{LITERATURE CITED}

Alderman, S. C., and Lacy, M. L. 1984. Influence of temperature and moisture on growth and sporulation of Botrytis squamosa. Can. J. Bot. 62:2793-2797.

Asher, M. J. C., and Thomas, C. E. 1984. Components of partial resistance to Erysiphe graminis in spring barley. Plant Pathol. 33:123-130.

Cave, G. L., Randall-Schadel, B., and Redlin, S. C. 2005. Risk analysis for Phytophthora ramorum Werres, deCock \& In't Veld, causal agent of Phytophthora canker (sudden oak death), ramorum leaf blight, and ramorum die-back. USDA-APHIS-PPQ Center for Plant Health Science and Technology, Plant Epidemiology and Risk Analysis Laboratory, Raleigh, NC.

Dart, N. L., and Chastagner, G. A. 2007. Estimated economic losses associated with the destruction of plants due to Phytophthora ramorum quarantine efforts in Washington State. Online publication. Plant Health Prog. doi.org/ 10.1094/PHP-2007-0508-02-RS

Davidson, J. M., Patterson, H. A., and Rizzo, D. M. 2008. Sources of inoculum for Phytophthora ramorum in a redwood forest. Phytopathology 98:860-866.

Davidson, J. M., Patterson, H. A., Wickland, A. C., Fichtner, E. J., and Rizzo, D. M. 2011. Forest type influences transmission of Phytophthora ramorum in California oak woodlands. Phytopathology 101:492-501.

Davidson, J. M., Rizzo, D. M., Garbelotto, M., Tjosvold, S., and Slaughter, G. W. 2002. Phytophthora ramorum and sudden oak death in California: II. Transmission and survival. Pages 741-749 in: U. S. Dep. Agric. For. Serv. Gen. Tech. Rep. PSW-GTR-184.

Davidson, J. M., Werres, S., Garbelotto, M., Hansen, E. M., and Rizzo, D. M. 2003. Sudden oak death and associated diseases caused by Phytophthora ramorum. Online publication. Plant Health Prog. doi.org/10.1094/PHP2003-0707-01-DG

Davidson, J. M., Wickland, A. C., Patterson, H. A., Falk, K. R., and Rizzo, D. M. 2005. Transmission of Phytophthora ramorum in mixed-evergreen forest in California. Phytopathology 95:587-596.

Denman, S., Kirk, S. A., Whybrow, A., Orton, E., and Webber, J. F. 2006. Phytophthora kernoviae and P. ramorum: Host susceptibility and sporulation potential on foliage of susceptible trees. Bull. OEPP/EPPO Bull. 36:373-376.

Dillard, H. R. 1989. Effect of temperature, wetness duration, and inoculum density on infection and lesion development of Colletotrichum coccodes on tomato fruit. Phytopathology 79:1063-1066.

Erwin, D. C., and Ribeiro, O. K. 1996. Phytophthora Diseases Worldwide. American Phytopathological Society Press, St. Paul, MN.

Ferguson, A. J., and Jeffers, S. N. 1999. Detecting multiple species of Phytophthora in container mixes from ornamental crop nurseries. Plant Dis. 83: 1129-1136.

Forney, C. F., and Brandl, D. G. 1992. Control of humidity in small controlledenvironment chambers using glycerol-water solutions. HortTechnology 2: $52-54$.

Frankel, S. J. 2008. Sudden oak death and Phytophthora ramorum in the USA: A management challenge. Australas. Plant Pathol. 37:19-25.

Frankel, S. J., and Palmieri, K. M. 2014. Sudden oak death, Phytophthora ramorum: A persistent threat to oaks and other tree species. Int. Oaks 25: 43-56.

Friedrich, S., Leinhos, G. M. E., and Lopmeier, F. J. 2003. Development of ZWIPERO, a model forecasting sporulation and infection periods of onion downy mildew based on meteorological data. Eur. J. Plant Pathol. 109:35-45.

Gigot, J. A., Gundersen, B., and Inglis, D. A. 2009. Colonization and sporulation of Phytophthora infestans on volunteer potatoes under Western Washington conditions. Am. J. Potato Res. 86:1-14.

Gilles, T., Phelps, K., Clarkson, J. P., and Kennedy, R. 2004. Development of MILLIONCAST, an improved model for predicting downy mildew sporulation on onions. Plant Dis. 88:695-702.

Griesbach, J. A., Parke, J. L., Chastagner, G. A., Grünwald, N. J., and Aguirre, J. 2011. Safe Procurement and Production Manual; A Systems Approach for the Production of Healthy Nursery Stock. Oregon Association of Nurseries, Wilsonville, OR.

Grünwald, N. J., Goss, E. M., Ivors, K., Garbelotto, M., Martin, F. N., Prospero, S., Hansen, E., Bonants, P. J. M., Hamelin, R. C., Chastagner, G., 
Werres, S., Rizzo, D. M., Abad, G., Beales, P., Bilodeau, G. J., Blomquist, C. L., Brasier, C., Brière, S. C., Chandelier, A., Davidson, J. M., Denman, S., Elliott, M., Frankel, S. J., Goheen, E. M., de Gruyter, H., Heungens, K., James, D., Kanaskie, A., McWilliams, M. G., Man in 't Veld, W., Moralejo, E., Osterbauer, N. K., Palm, M. E., Parke, J. L., Perez Sierra, A. M., Shamoun, S. F., Shishkoff, N., Tooley, P. W., Vettraino, A. M., Webber, J., and Widmer, T. L. 2009. Standardizing the nomenclature for clonal lineages of the sudden oak death pathogen, Phytophthora ramorum. Phytopathology 99:792-795.

Harikrishnan, R., and del Rio, L. E. 2006. Influence of temperature, relative humidity, ascospore concentration, and length of drying of colonized dry bean flowers on white mold development. Plant Dis. 90:946-950.

Hildebrand, P. D., and Sutton, J. C. 1984. Interactive effects of the dark period, humid period, temperature, and light on sporulation of Peronospora destructor. Phytopathology 74:1444-1449.

Hüberli, D., Lutzy, B., Voss, B., Calver, M., Ormsby, M., and Garbelotto, M. 2008. Susceptibility of New Zealand flora to Phytophthora ramorum and pathogen sporulation potential: An approach based on the precautionary principle. Australas. Plant Pathol. 37:615-625.

Jeffers, S. N., and Martin, S. B. 1986. Comparison of two media selective for Phytophthora and Pythium spp. Plant Dis. 70:1038-1043.

Jesperson, G. D., and Sutton, J. C. 1987. Evaluation of a forecaster for downy mildew of onion (Allium cepa L.). Crop Prot. 6:95-103.

Lamari, L. 2002. ASSESS: Image Analysis Software for Plant Disease Quantification. American Phytopathological Society, St. Paul, MN.

Linderman, R. G., and Davis, E. A. 2007. Comparative host susceptibility and sporulation potential of Phytophthora ramorum on species, cultivars, and hybrids of Camellia. Online publication. Plant Health Prog. doi.org/ 10.1094/PHP-2007-0822-02-RS

Mehta, Y. R., and Zadoks, J. C. 1970. Uredospore production and sporulation period of Puccinia recondita $\mathrm{f}$. sp. triticina on primary leaves of wheat. Neth. J. Plant Pathol. 76:267-276.

Melching, J. S., Bromfield, K. R., and Kingsolver, C. H. 1983. The plant pathogen containment facility at Frederick, MD. Plant Dis. 67:717-722.

Minitab, Inc. 2010. Minitab 17 Statistical Software. Computer software. Minitab, Inc., State College, PA.

Moralejo, E., Garcia Munoz, J. A., and Descals, E. 2006. Insights into Phytophthora ramorum sporulation: Epidemiological and evolutionary implications. Bull. OEPP/EPPO Bull. 36:383-388.

Parlevliet, J. E., and Van Ommeren, A. 1975. Partial resistance of barley to leaf rust, Puccinia hordei. II. Relationship between field trials, micro plot tests and latent period. Euphytica 24:293-303.

Quinn, J. A., and Fujimoto, T. T. 1986. Computer graphics simulation of growth and sporulation of Erysiphe polygoni. Phytopathology 76:883-888.

Rizzo, D. M., Garbelotto, M., Davidson, J. M., Slaughter, G. W., and Koike, S. T. 2002. Phytophthora ramorum as the cause of extensive mortality of Quercus spp. and Lithocarpus densiflorus in California. Plant Dis. 86: 205-214.

Rossi, V., Scandolara, A., and Battilani, P. 2009. Effect of environmental conditions on spore production by Fusarium verticillioides, the causal agent of maize ear rot. Eur. J. Plant Pathol. 123:159-169.

Rouse, D. I., Nelson, R. R., MacKenzie, D. R., and Armitage, C. R. 1980. Components of rate-reducing resistance in seedlings of four wheat cultivars and parasitic fitness in six isolates of Erysiphe graminis f. sp. tritici. Phytopathology 70:1097-1100.

Sansford, C., Inman, A., and Webber, J. 2010. Development of a pest risk analysis for Phytophthora ramorum for the European Union; the Key Deliverable from the EU Funded Project RAPRA. Pages 139-153 in: Proc. Sudden Oak Death Fourth Sci. Symp. S. J. Frankel, J. T. Kliejunas, and K. M. Palmieri, eds. Gen Tech. Rep PSW-GTR-229. U.S. Department of Agriculture Forest Service, Pacific Southwest Research Station, Albany, CA.
SAS Institute, Inc. 2008. SAS/STAT 9.2 User's Guide. SAS Institute Inc., Cary, NC.

Shishkoff, N. 2006. Susceptibility of Camellia to Phytophthora ramorum. Online publication. Plant Health Prog. doi.org/10.1094/PHP-2006-0315-01RS

Sokal, R. R., and Rohlf, F. J. 1995. Biometry, 3rd ed. W. H. Freeman and Company, New York.

Suslow, K. 2006. Phytophthora ramorum-Economic impacts and challenges for the nursery industry. Pages 41-44 in: Proc. Sudden Oak Death Second Sci. Symp.: The State of Our Knowledge. S. J. Frankel, P. J. Shea, and M. I. Haverty, eds. Gen. Tech. Rep. PSW-GTR-196. U.S. Department of Agriculture Forest Service, Pacific Southwest Research Station, Albany, CA.

Suslow, K. 2008. Recommended industry best management practices for the prevention of Phytophthora ramorum introduction in nursery operations. Pages 115-128 in: Proc. Sudden Oak Death Third Sci. Symp. S. J. Frankel, J. T. Kliejunas, and K. M. Palmieri, tech. coord. Gen. Tech. Rep. PSWGTR-214. U.S. Department of Agriculture Forest Service, Pacific Southwest Research Station, Albany, CA.

Tooley, P. W., and Browning, M. 2009. Susceptibility to Phytophthora ramorum and inoculum production potential of some common Eastern forest understory plant species. Plant Dis. 93:249-256.

Tooley, P. W., and Browning, M. 2015. Temperature effects on the onset of sporulation by Phytophthora ramorum on Rhododendron 'Cunningham's White'. J. Phytopathol. 163:908-914.

Tooley, P. W., and Browning, M. 2016. The effect of exposure to decreasing relative humidity on the viability of Phytophthora ramorum sporangia. J. Phytopathol. 164:874-881.

Tooley, P. W., Browning, M., and Berner, D. 2008. Recovery of Phytophthora ramorum following exposure to temperature extremes. Plant Dis. 92: 431-437.

Tooley, P. W., Browning, M., and Leighty, R. M. 2011. Infectivity and sporulation of Phytophthora ramorum on Northern red oak and chestnut oak. J. Phytopathol. 159:516-521.

Tooley, P. W., and Carras, M. M. 2011. Enhanced recovery of Phytophthora ramorum from soil following 30 days of storage at $4^{\circ} \mathrm{C}$. J. Phytopathol. 159: 641-643.

Tooley, P. W., Kyde, K. L., and Englander, L. 2004. Susceptibility of selected ericaceous ornamental host species to Phytophthora ramorum. Plant Dis. 88:993-999.

Tukey, J. 1949. Comparing individual means in the analysis of variance. Biometrics 5:99-114.

USDA-APHIS. 2012. Federal Order: Domestic quarantine for Phytophthora ramorum DA-2012-03 January 25, 2012. Online publication. https://www. aphis.usda.gov/plant_health/plant_pest_info/pram/downloads/pdf_files/ SPRO_\%20DA-2012-03.pdf

USGAO. 2006. Invasive forest pests. Lessons learned from three recent infestations may aid in managing future efforts. GAO-06-353. United States Government Accountability Office (USGAO), Washington, DC.

Vettraino, A. M., Huberli, D., and Garbelotto, M. 2008. Phytophthora ramorum infection of coast live oak leaves in Californian forests and its capacity to sporulate in vitro. Australas. Plant Pathol. 37:72-73.

Villareal, R. L., Nelson, R. R., MacKenzie, D. R., and Coffman, W. R. 1981. Some components of slow-blasting resistance in rice. Phytopathology 71: 608-611.

Werres, S., Marwitz, R., Man In't Veld, W. A., De Cock, A. W. A. M., Bonants, P. J. M., De Weerdt, M., Themann, K., Ilieva, E., and Baayen, R. P. 2001. Phytophthora ramorum sp. nov., a new pathogen on Rhododendron and Viburnum. Mycol. Res. 105:1155-1165.

Winston, P. W., and Bates, D. H. 1960. Saturated solutions for the control of humidity in biological research. Ecology 41:232-237. 